\title{
Sciendo
}

ACTA UNIVERSITATIS CIBINIENSIS - TECHNICAL SERIES

Vol. 712019

\section{STUDY OF PHONIC POLLUTION PRODUCED BY CAR TRAFFIC IN PETROSANI}

\author{
Andreea Cristina Tataru \\ University of Petrosani, Universitatii street, No.20, Petrosani, Hunedoara, Roumania \\ Aurora Stanci \\ University of Petrosani, Universitatii street, No.20, Petrosani, Hunedoara, Roumania
}

\begin{abstract}
One of the most recent global environmental problems is noise pollution. Noise pollution is a component of environmental pollution. Like any other type of pollution, noise pollution has negative effects on environmental factors. The main sources of noise are: industry, urban areas and transport. To reduce the level of noise pollution is necessary to determine the pollution sources that cause. In this paper we will study the main areas affected by the noise pollution caused by the traffic in the city of Petrosani. We will also present solutions for reducing the pollution of the affected areas in Petrosani.
\end{abstract}

\section{Introduction}

Road traffic is the main component of city noise. During one day, three peak noise levels are recorded at 6-7, 12 and 18-19 hours.

Air cooled, high-powered cars, motorcycles and scooters produce the highest noise levels between 75 and $92 \mathrm{~dB}$. [3]

Braking and starting are the noisiest for all types of cars. Diesel engines are the noisiest polluting. [3]

\section{Theoretical considerations}

Noise pollution is an important component of environmental pollution, both by harmful character and he is present in all day to day activities of modern life. The noise pollution is a major problem for all economically developed countries or developing countries. Noise pollution is a continue aggression, determined by different noises made by machinery, industrial equipment or domestic, inside or outside buildings, noise favoured by the placement and their constructive isolation.

One of the disturbing factors of the environment, that influence the environment in which it operates and human life is the noise which is associated and identified in generally by noise pollution. [5]

Annoying sounds, no matter what are their nature, are noisy. They have a harmful influence on the nervous system, causing a tiredness.

Sounds can be propagated by air, called sounds or aerial noises, or solid environments (building elements), called sounds or structural noises.

The most important parameters for impact noise are the mass and speed of the bodies that hit, as well as the duration of the impact. These noises are widespread zombies, dominating high frequencies due to the short duration of the impact. Regular impact generates periodic noise.

Rolling noise is the result of asperities or irregularities in the running area contact area. The rolling noise is encountered on ball bearings, conveyor systems, rail vehicles and road vehicles. The running noise also depends on the elasticity of the contact areas. The spectral composition of rolling noise is broadband.

Magnetic fields occur in electric motors to generate drive torques in rotation. The uneven variation of the torque that produces force change on the bearings can cause vibrations. Magnetic induced noise is depend ending on the load.

Inertia forces can contribute to noise generation through effects such as impact, run, friction, or pulsation. Inertia forces are induced by oscillating masses, unbalanced or rotating parts (roller bearings produce important rolling noise through inertial forces). 
Friction forces through soldering and sliding phenomena are potential sources of noise. Sliding usually generates broadband noises, but the excitation of resonances of the structure can produce high-intensity tonal components in the noise.

At the crossing of the propagation medium, the acoustic waves loose some of the energy initially contained due to the following physical causes: the internal friction of the particles of the environment whose particles enter the oscillation (the environmental viscosity), the thermal conductivity of the environment, the heat radiation and the intermolecular energy exchange. This attenuation is added to that produced by the receiver's distance from the sound source. $[1,2,4]$ noise pollution

\section{Results and discussion}

Industry, road and rail traffic are the main sources of noise in the city of Petrosani, which affects the population.

Petroşani municipality is situated at the confluence of West Jiu with the Eastern Jiu. Is surrounded by mountain massifs Retezat (north), Valcan (south), Parang (east) and Godeanu (west).

The total length of the road network in Petrosani is about $120 \mathrm{~km}$. More than $12 \mathrm{~km}$ of the road network of Petrosani is represented by 4-lane roads. The main artery is 1 Decembrie 1918 Petrosani Street. Another important artery is the road segment DN66 that runs through Petrosani. This is the transit road connecting Hateg and Tg-Jiu and is parallel to the Petroşani-Tg Jiu railway. (fig. 1)

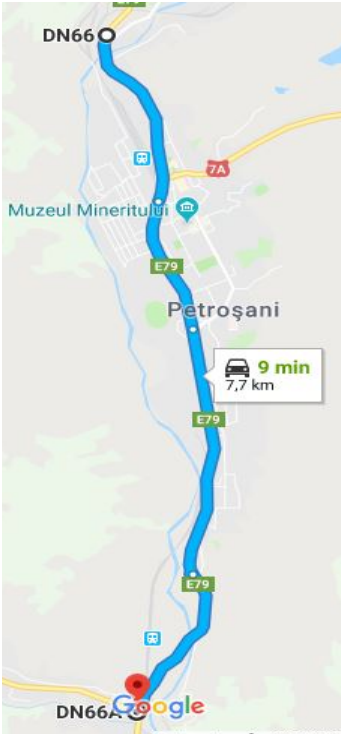

Transit road DN66

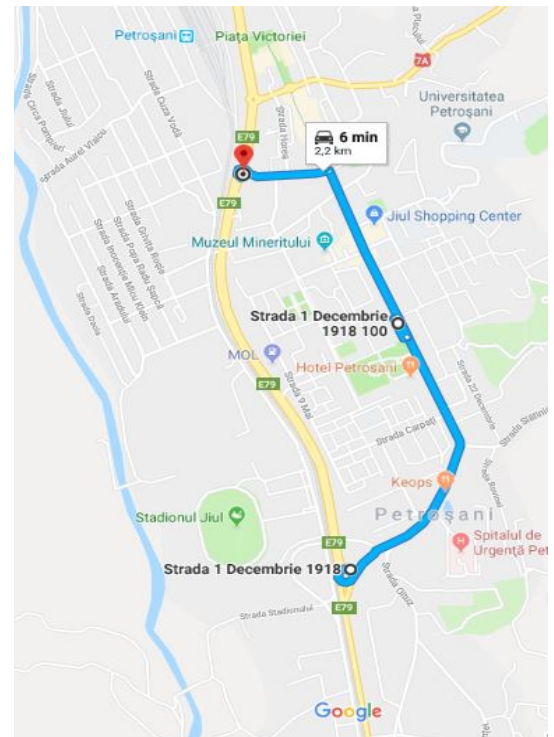

Street 1 Decembrie 1918

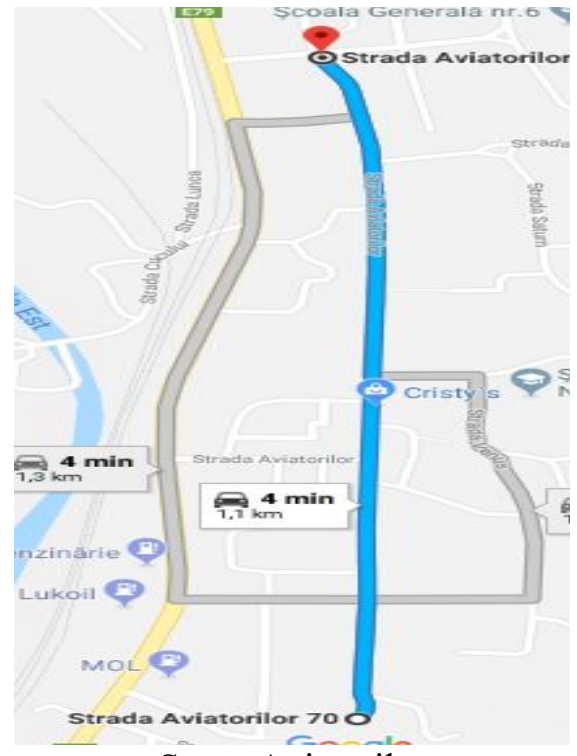

Street Aviatorilor

Fig. 1 lane segments of the Petroşani municipality

The north-south axis of the city is made up of the streets of Fabrici, Livezeni, December 1, 1918, and next to the stadium a new artery that passes by Victoriei Square, then on Darmanesti Street in the direction of Hateg. (Fig. 2)

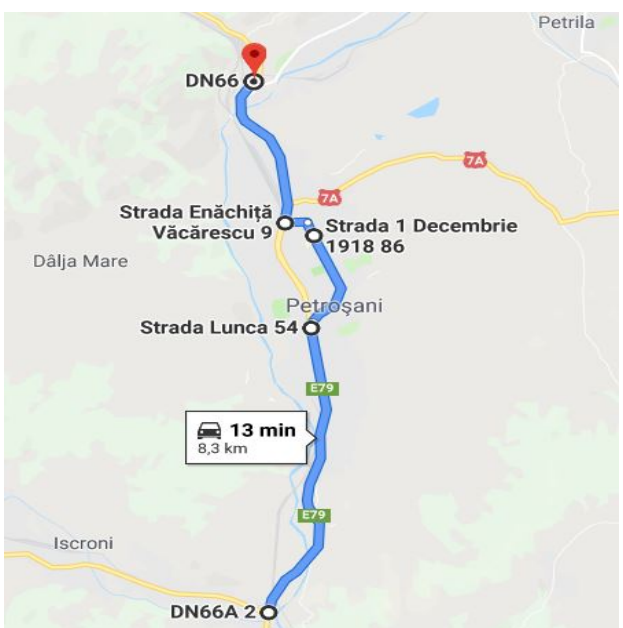

Fig. 2 North-South axis of Petrosani Municipality 
The city of Petroşani is crossed by the road connecting Oradea-Deva-Petrosani-Tg. Jiu-Craiova and will be modernized to become an express road.

Petroşani municipality is located on the north-south railway axis connecting Transylvania to Oltenia through the Jiu Valley (Simeria-Petrosani-Tg. Jiu-Filiasi) To Transylvania there is the Petrosani-Simeria railway axis (with branches to the main cities (Deva, Arad, Cluj ).

An important source of noise is road traffic, considering that the Petrosani is crossed by DN 66, which connects the south, central and western parts of the country. In order to determine the noise caused by road traffic on this road section, we selected 4 points as follows: P1 and P8 - Dacia area, P2 - roundabout airplane and P3 - roundabout DN 66 with 1 December 1918. At point P1, measurements have also been carried out to determine the level of noise produced by rail traffic (Fig. 3).

In order of determining the noise level in Petrosani we chose three more points where traffic is intense, the areas where we chose the points being part of the central area of Petrosani. Point P4 - market intersection, P5 - area of the first floor in the market area and P6 - roundabout, hospital (Fig. 3).

In order to determine the noise, we have used the PCE-222 multimeter, it is a multifunctional sound level meter (with acoustic, light, temperature and relative humidity sensor) with RS-232 interface and software compatible with Windows, with an accuracy of $\pm 3.5 \mathrm{~dB}$ in acoustic intensity measurement.

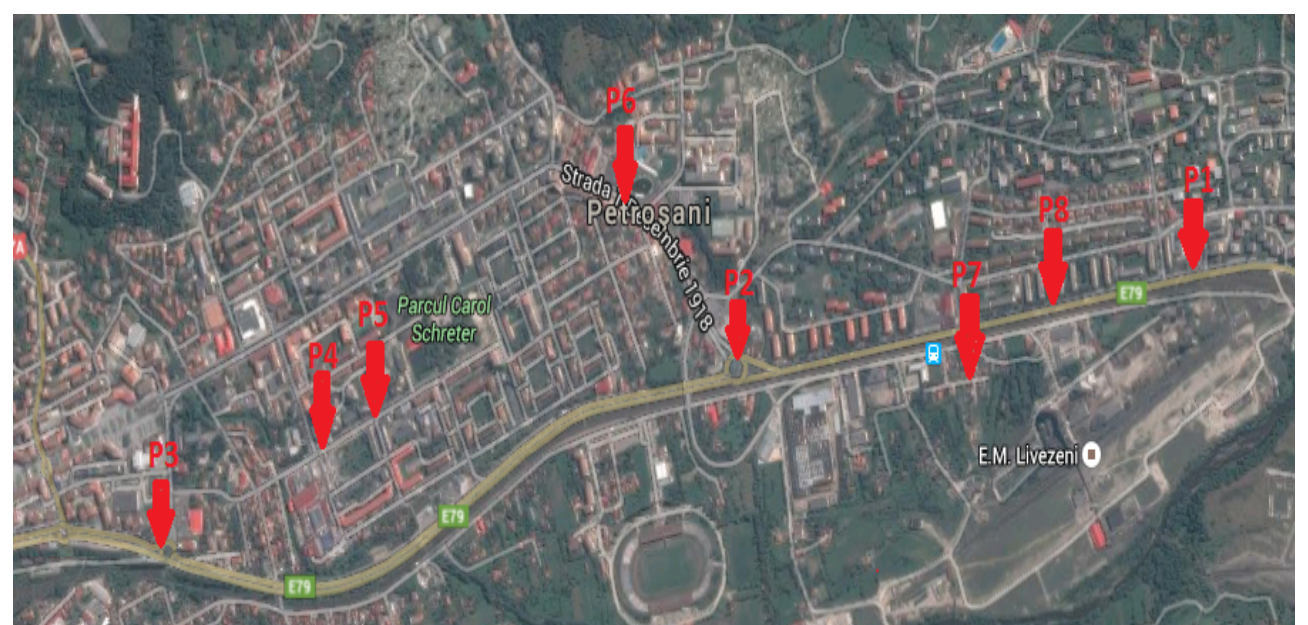

Fig. 3 Locating of the points where the measurements were made to determine the noise pollution in Petrosani Municipality

Measurements were made in accordance with existing standards at a distance of $2.00 \mathrm{~m}$ from the dwelling facade and height of $1.30 \mathrm{~m}$ from the soil during 10 days at time intervals 10-11, 13-14 and 1718 of each day.

The permissible limits of Lech equivalent noise levels for buildings protected during daytime are 55 $\mathrm{dB}$. The maximum allowable night noise level is $10 \mathrm{~dB}$ lower than during the day.

The determinations were performed according to the current STAS during the day and were calculated using the relationship:

$$
\text { Lech }=\text { Lmax }-1 / 3(\text { Lmax-Lmin) }
$$

Average values of the equivalent noise level for each measurement point are shown in Tables 1.

Following the monitoring of road traffic in the Airport District, the Dacia area of Petrosani Municipality, it was found that the maximum permissible noise level for the inhabited area is exceeded during the day due to the road and railway traffic (P1).

Average daytime noise at peak hours of road traffic near the blocks in the Downtown Airport area, Dacia, located on the edge of the European Road E79, is $83 \mathrm{~dB}$.

The maximum permissible noise level in the Downtown Airport area of Dacia in the city of Petrosani during the day is exceeded by approximately $27 \mathrm{~dB}$ for the E79 road blocks and by $15 \mathrm{~dB}$ for the rest of the houses. 
Table 1. Average Noise level equivalent values according to time interval 10-11

\begin{tabular}{|c|c|c|c|c|c|c|c|c|c|c|}
\hline \multirow{2}{*}{$\begin{array}{c}\text { Time } \\
\text { inter } \\
\text { val }\end{array}$} & \multicolumn{80}{|c|}{$\begin{array}{c}\text { Lech - } \\
\text { between the } \\
\text { hours } \\
9: 30-10 \\
{[\mathrm{~dB}]}\end{array}$} \\
\cline { 2 - 12 } & P1 & P2 & P3 & P4 & P5 & P6 & P7 & P8 & P8a & P1 rail road \\
\hline $10-$ & 85, & 78,8 & 76, & 64, & 45, & 67, & 59, & 62, & 84,8 & 89,8 \\
11 & 2 & & 9 & 9 & 6 & 3 & 7 & 2 & & \\
\hline $13-$ & 84, & 75,8 & 75, & 66, & 47, & 64, & 59, & 61, & 83,1 & - \\
14 & 2 & & 9 & 3 & 2 & 6 & 6 & 8 & & \\
\hline $17-$ & 82, & 73,1 & 75, & 65, & 42, & 67, & 60, & 62, & 80,8 & - \\
18 & 2 & & 3 & 6 & 4 & 2 & 3 & 4 & & \\
\hline
\end{tabular}

Average daytime noise at peak traffic hours between houses in the Dacia area is $70 \mathrm{~dB}$.

The value of the noise generated by the railway traffic in the Dacia area is $90 \mathrm{~dB}$.

Following the monitoring of road traffic in the Airport District, the Dacia area of Petrosani Municipality, it was found that the maximum allowed noise pollution for the inhabited area is exceeded during the day due to the road and railway traffic.

The records obtained in points $\mathrm{P} 2$ and $\mathrm{P} 3$, two roundabouts in unpopulated areas linking the center and the road belt of Petrosani. Noise pollution reaches these areas to a maximum of $79.1 \mathrm{~dB}$, and trucks are also circulating in this area.

From the analysis of the registration obtained at point P4, the traffic light at the market, high noise levels are observed when leaving the traffic lights. From the analyzes performed, a high level of noise was observed in the case of motorcycles.

\section{Conclusions}

An important source of noise pollution in the city of Petrosani is given by road and rail traffic.

Throughout the length of the National Road that passes through Petrosani municipality, it can be seen that the limit of allowed noise pollution for the inhabited area is exceeded during the day due to road traffic (average values of $83 \mathrm{~dB}$ ) and rail.

The recordings obtained in points $\mathrm{P} 2$ and $\mathrm{P} 3$, two roundabouts in unpopulated areas connecting the center and the road belt of Petroşani Municipality have the average of $79.1 \mathrm{~dB}$.

Petrosani is a city that has a high value of noise pollution due to traffic and rail traffic, especially in the areas of the National Road (Petrosani) and along the railway.

\section{References}

1. A. Benliay, M. Ozyavuz, S. Cabuk, M. Gunes, JEPE, No 1, 113-122, (2019).

2. A. C. Stanci (Tataru), Cercetări științifice în domenii prioritare pentru dezvoltarea cunoașterii și a proceselor inovative, Editura UNIVERSITAS, ISBN 978-973-741-457-1, pag. 449 - 492, Petroșani, (2015).

3. A. O. Tritean, M. Arghir, A XIII-a Conferință Națională multidisciplinară - cu participare internațională, "Profesorul Dorin Pavel- fondatorul hidrienergeticii românești", Sebeși, (2013).

4. A. Stanci, A. Stanci, D. Tataru, SIMPRO" 2014, ISSN-L, (2014).

5. M. Albulescu, Revistă de Informare, Asociaţia de Promovare a Ştiinţei, Tehnicii şi Informării Corecte şi a Proiectului NanoPol, (2009). 